\title{
Predictors associated with sickle cell nephropathy: a systematic review
}

\author{
Lauana Maurício $^{1 *} \odot$, Sara Ribeiro ${ }^{1} \odot$, Luciana Santos $^{1} \odot$, Denismar Borges de Miranda
}

\section{SUMMARY}

INTRODUCTION: Sickle cell anemia affects more than 30 million people worldwide. Chronic kidney disease develops in $40 \%$ of individuals. The death rate of patients with sickle nephropathy is still high, with little known predictors related to its development. To answer the question "What predictors are associated with the onset of chronic kidney disease in patients with sickle cell anemia?", this article seeks to contribute to a better understanding of sickle nephropathy, making possible a new look at the sickle cell anemia and its kidney complications.

METHODS: A systematic review was developed, using the PRISMA recommendation, for cohort studies on predictors related to the outcome of sickle nephropathy in patients with sickle cell anemia.

RESULTS: Initially 321 studies were identified in Pubmed, of which six were selected to compose this systematic review. Lower hemoglobin levels, increased ages and albuminuria were the most pointed predictors associated with chronic kidney disease.

CONCLUSION: The main predictors associated with the development of chronic kidney disease in individuals with sickle cell anemia were lower hemoglobin levels, increased ages, and albuminuria. New studies evaluating predictors for the development of chronic kidney disease in sickle cell anemia are needed to better understand its installation and prevent its progression.

KEYWORDS: Acute kidney injury. Renal insufficiency, chronic. Anemia, sickle cell.

\section{INTRODUCTION}

Sickle cell anemia (SCA) was presented by Linus Pauling in 1949 as an autosomal recessive disease in which multiple organs are affected $^{1}$ and ever since it has become a prevalent genetic disease in the world: more than 30 million people are affected worldwide $^{2}$. A meta-analysis published in 2018 estimated the prevalence of patients with SCA to be 111.91 for every 100,000 live births $^{3}$. In Brazil, between 25,000 and 50,000 cases of SCA are estimated, according to the Ministry of Health ${ }^{4}$. Chronic kidney disease (CKD) develops in 40\% of individuals, and 15-30\% die due to kidney complications ${ }^{5}$. Among individuals who reach the fourth decade of life, half have end-stage kidney damage ${ }^{6}$.
In the last decades, the average life expectancy of patients with SCA has increased thanks to better management of the numerous complications of the disease, including sickle nephropathy $(\mathrm{SN})^{7}$. However, the death rate of patients with $\mathrm{SN}$ is still high, with little known predictors related to its development ${ }^{8}$. To answer the question "What predictors are associated with the onset of CKD in patients with SCA?", this article seeks to contribute towards a better understanding of $\mathrm{SN}$, making possible a new look at the SCA and its kidney complications, which will contribute towards early detection, better management and, consequently, an improvement in the prognosis of the disease.

'Pontifícia Universidade Católica de Goiás - Goiânia (GO), Brazil.

*Corresponding author: Ivanessasm@outlook.com

Conflicts of interest: the authors declare there are no conflicts of interest. Funding: none.

Received on November 06, 2020. Accepted on November 16, 2020. 


\section{METHODS}

A systematic review was developed, using the PRISMA ${ }^{9}$ recommendation, for cohort studies on predictors related to the outcome of SN in patients with SCA.

Through 4 strategies with the keywords "sickle cell anemia", "renal insufficiencies" and "chronic renal insufficiencies", as well as their synonyms, with the interlocutors AND or OR, through PubMed database (http://www.pubmed.gov.), original full text articles were searched, as the example: $\{$ (“'renal insufficiency, chronic" [ MeSH Terms] OR ("renal” [All Fields] AND "insufficiency" [All Fields] AND "chronic" [All Fields]) OR "chronic renal insufficiency" [All Fields] OR ("chronic" [All Fields] AND " renal "[All Fields] AND” insufficiencies "[All Fields]) OR" chronic renal insufficiencies "[All Fields]) AND (" sickle cell anemia "[All Fields] OR" anemia, sickle cell "[MeSH Terms] OR ( "anemia" [All Fields] AND "sickle" [All Fields] AND "cell" [All Fields]) OR "sickle cell anemia" [All Fields] OR ("sickle" [All Fields] AND "cell" [All Fields ] AND "anemia” [All Fields])) AND (“2009/10/28” [PDat]: "2019/10/25” [PDat] AND "humans" [MeSH Terms]).

Two researchers (LVSM and SMSR) independently and blindly analyzed the titles and abstracts of the articles found. The divergences were analyzed by a third researcher (LRS). After that, a full-text reading was done applying the inclusion criteria: articles published in the period between 10/27/2009 and 10/25/2019; cohort original articles; studies in which measures of creatinine clearance have been obtained by previously validated means; studies carried out in humans. The exclusion criteria were: articles which only address patients with sickle cell trait/other hemoglobinopathies and those that do not address predictors in patients with kidney injury.
For each full text selected, the $\mathrm{CASP}^{10}$ questionnaire was applied to assess the methodological quality and possible bias. A manual search was performed on the references of the selected articles, to select an article that had not been included in our search key. Then, the predictors cited by the articles that had a p-value less than 0.05 were extracted and arranged in a table according to the highest frequency.

\section{RESULTS}

Initially, 321 studies were identified in PubMed, of which six were selected to compose this systematic review, as shown in Figure 1.

Of the six selected studies, five were developed in the United States ${ }^{11-15}$ and one in Brazil ${ }^{16}$. Table 1 summarizes the main

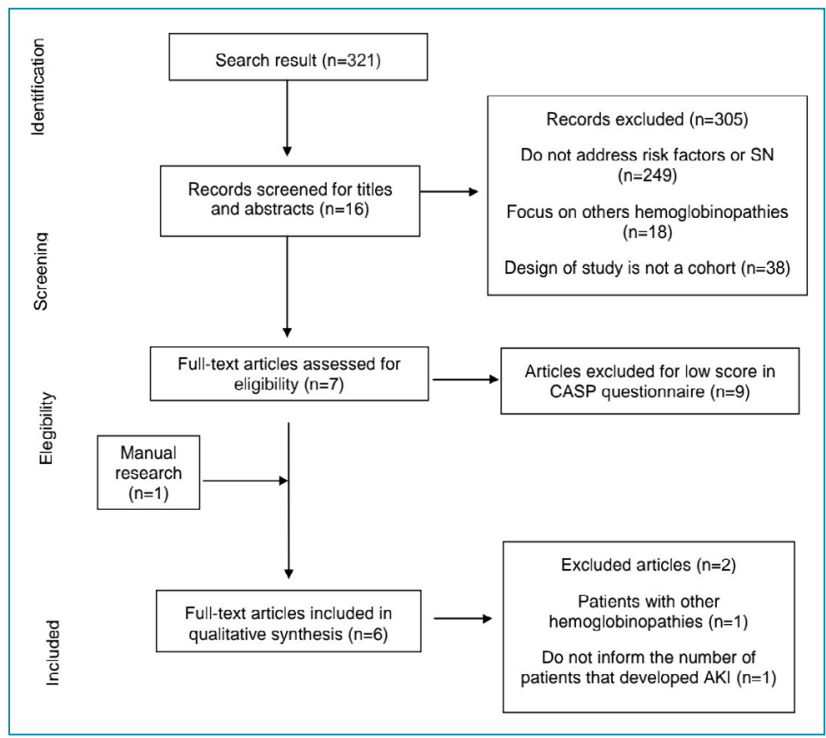

Figure 1. Flow of phases of the research.

Table 1. Results of analyzed articles.

\begin{tabular}{|c|c|c|c|}
\hline Article & $\mathrm{n}$ & $\begin{array}{c}\text { Age } \\
\text { (Years/mean) }\end{array}$ & Risk factors $(p<0.05)$ \\
\hline Lebensburger, $2011^{13}$ & 144 & - & Lower Hb levels, lower HbF levels and incresead LDH. \\
\hline Aygun, $2011^{11}$ & 260 & $\leq 30$ & $\begin{array}{l}\text { Increased cystatin C levels, higher systolic blood pressure, decreased } \\
\text { leukocytes count and decreased absolute neutrophil counts. }\end{array}$ \\
\hline McPherson Yee, $2011^{15}$ & 261 & $2-21$ & Increased age, lower Hb levels. \\
\hline Silva Junior, 201216 & 98 & $19-67$ & $\begin{array}{l}\text { Lower } \mathrm{Hb} \text { levels, lower hematocrit levels, lower platelet levels, } \\
\text { leukocyturia, proteinuria and increased age. }\end{array}$ \\
\hline Saraf, 201414 & 795 & $24-46$ & $\begin{array}{l}\text { Higher mean arterial pressure, lower Hb levels, macroalbuminuria, } \\
\text { haemoglobinuria, increased age, AST, incresead LDH. }\end{array}$ \\
\hline Gosmanova, 201412 & 98 & $21-42$ & $\begin{array}{l}\text { Increased age, higher systolic and diastolic blood pressure, } \\
\text { albuminuria. }\end{array}$ \\
\hline
\end{tabular}

CKD: chronic kidney disease; AKI: acute kidney injury; Hb: hemoglobin; HbF: fetal hemoblogin; CRP: C-reactive protein; AST: aspartate transaminase; LDH: lactate dehydrogenase; NGAL: urine neutrophil gelatinase-associated lipocalin; BMI: body mass index. 
characteristics of the six studies and the respective predictors associated with CKD in patients with SCA.

Lower levels of hemoglobin, albuminuria and increased age were the main predictors shown in the studies. Other important predictors presented were increased LDH (lactate dehydrogenase), higher blood pressure, lower levels of fetal hemoglobin, among others listed in Table 2.

\section{DISCUSSION}

Lower levels of hemoglobin were suggested as important predictors for CKD. However, CKD caused by other diseases can also lead to anemia, which raises the question: is CKD linked to anemia or is anemia a predictor of SN? Naik et al. described the pathophysiology of SN, correlating with anemia. The red blood cells of patients with AF when in vessels with lower oxygen tension or lower $\mathrm{pH}$ polymerize, taking the form of a sickle, occluding small diameter vessels and leading to ischemic lesions in multiple organs, including the kidney. This also leads to glomerular microinfarctions and apoptosis of epithelial cells, which can decrease the glomerular filtration rate ${ }^{17}$.

Patients that developed CKD had greater ages when compared to patients without kidney injury. These data are consistent

Table 2. Risk factors associated with SN ( $n=7)$.

\section{Risk factors}

\begin{tabular}{l|l}
\hline Lower Hb levels & 4 \\
\hline Increased age & 4 \\
\hline Albuminuria & 3 \\
\hline Increased LDH & 2 \\
\hline Higher systolic blood pressure & 2 \\
\hline Higher diastolic blood pressure & 1 \\
\hline Lower HbF levels & 1 \\
\hline Lower Hematocrit levels & 1 \\
\hline Decreased leukocytes count & 1 \\
\hline Decreased absolute neutrophil count & 1 \\
\hline Lower platelet levels & 1 \\
\hline Haemoglobinuria & 1 \\
\hline Leukocyturia & 1 \\
\hline AST & 1 \\
\hline Higher MAP & 1 \\
\hline Increased cystatin C levels & 1
\end{tabular}

SN: sickle nephropathy; Hb: hemoglobin; HbF: fetal hemoglobin; CRP: C-reactive protein; LDH: lactate dehydrogenase; MAP: mean arterial pressure; NA: not assessed. with a 4 decades study developed with 1056 patients, which demonstrated that renal injury tends to occur later, around the third to fourth decades of life ${ }^{18}$.

Albuminuria and proteinuria were also prevalent predictors. The literature points to other studies that demonstrate albuminuria as a predictor linked to the pathogenesis of podocyte loss and disruption of the glomerular filtration barrier ${ }^{19}$. Podocytes are the epithelial cells that line the glomerular capillaries through their foot processes and are responsible for the composition of the glomerular filtration membrane, together with the porous endothelial cells and the glomerular basement membrane. They serve as a barrier by holding proteins through size and load-dependent blocking. As podocytes have their own metabolism, ischemic lesions, toxins, complement deposition, among other situations, lead to the production of reactive oxygen species that induce apoptosis and podocyte processes effacement, through the destruction of the actin cytoskeleton, changes in the negative podocyte surface and failure of calcium metabolism. Vasooclusive episodes occur in SCA patient's vessels, culminating with ischemic lesions to the kidneys. All of these result in the failure of the filtration barrier and trigger proteinuria ${ }^{20,21}$.

Arterial hypertension was positively correlated with the development of CKD in individuals with SCA, through higher systolic and diastolic blood pressure seen in CKD patients. Corroborating these findings, a cohort of 158 patients with SCA showed a $50 \%$ increase in creatinine levels in patients with systolic blood pressure levels above $140 \mathrm{mmHg}$ or diastolic blood pressure above $90 \mathrm{mmHg}^{22}$.

Urinary and serum markers such as lactic dehydrogenase, AST, cystatin C, leukocyturia, and hemoglobinuria were related to the development of renal injury, which suggests that hemolysis and inflammation are present in the pathophysiology of the nephropathy. Fetal hemoglobin was shown as a protective factor as it prevents red blood cells from acquiring the sickle shape ${ }^{17}$.

A small sample study demonstrated a decrease in lactic dehydrogenase in patients with SCA who were treated with hydroxyurea. Also, the same study reported lower reticulocyte counts and higher levels of fetal hemoglobin, findings that suggest a reduction in hemolysis in patients receiving hydroxyurea and also show that hemolysis is an important feature in patients with SCA. A larger cohort also demonstrated that lactic dehydrogenase is associated with higher mortality in individuals with SCA, reaffirming that hemolysis is a predictor of poor prognosis in these patients ${ }^{23,24}$.

Higher levels of AST were pointed in the studies of this review as predictors of SCA, but other articles in the literature have correlated higher levels of AST, as well as bilirubin and alanine aminotransferase, with another organ failure in SCA: the sickle cell hepatopathy, as demonstrated in the cohort 
developed with more than 1100 subjects. On the other hand, this study does not present any parameter related to kidney function, which provides the missing information of whether AST is related or not with $\mathrm{SN}^{25}$. However, Madu et al. correlated AST levels and proteinuria, without statistical significance, which also indicates a poor correlation between this predictor and kidney injury ${ }^{26}$.

A study published in 1985 with patients with renal dysfunction caused by multiple diseases, associated decreased glomerular filtration rate with increased levels of cystatin $\mathrm{C}^{27}$. Our study also demonstrated an association between this marker and reduced renal function in patients with SCA, but recent studies have conflicted with these findings. Unal et al. for example, showed no difference in cystatin C levels between SCA patients and healthy controls ${ }^{28}$. On the other hand, a Greece study developed with 87 patients found an inverse correlation between glomerular filtration rate and cystatin $\mathrm{C}$ levels, corroborating with the previous findings of the 1985 study $^{29}$. All this controversy raises the need for further research on this marker.

Regarding urinary markers, leukocyturia and hemoglobinuria did not correlate with proteinuria in a cross-sectional study conducted in Africa, which differs from our findings $s^{30}$. However, other reports have shown that hemoglobinuria is related to $\mathrm{SN}$ as a sign of papillary necrosis, congestion of the renal vasculature, and even renal medullary carcinoma ${ }^{31-33}$.

Our study has some limitations. Few cohort studies evaluating the development of kidney injury in patients with SCA have been found in the databases, which demonstrates the need for further studies on this topic. In addition, there is high heterogeneity among the articles, with several measures of creatinine clearance and different criteria of albuminuria.

\section{CONCLUSION}

In conclusion, the main predictors associated with the development of CKD in individuals with SCA were lower hemoglobin levels, albuminuria, and increased age. New studies evaluating the pathophysiology of kidney injury in SCA are needed to better understand its installation and prevent its progression.

\section{ACKNOWLEDGMENTS}

We would like to acknowledge professor Antônio Wilson Soares de Oliveira and Antônio Márcio Teodoro Cordeiro Silva, as well as the teaching staff of the Pontifícia Universidade Católica de Goiás, for all the support to this project.

\section{AUTHORS" CONTRIBUTIONS}

LM: Conceptualization, Data Curation, Methodology. SR: Conceptualization, Data Curation, Methodology, Writing - Original Draft. LS: Writing - Original Draft, Writing Review \& Editing. DBM: Methodology, Writing - Original Draft, Writing - Review \& Editing.

\section{REFERENCES}

1. Pauling L, Itano HA. Sickle cell anemia, a molecular disease. Science. 1949;109(2835):443. PMID: 18213804

2. World Health Organization. Sickle-cell anaemia: report by the Secretariat. Geneva: World Health Organization; 2006. [cited on Jan. 23, 2019]. Available from: https://apps.who.int/iris/ handle/10665/20890

3. Wastnedge E, Waters D, Patel S, Morrison K, Goh MY, Adeloye $D$, et al. The global burden of sickle cell disease in children under five years of age: a systematic review and meta-analysis. J Glob Health. 2018;8(2):021103. https://doi.org/10.7189/ jogh.08.021103

4. Ministério da Saúde. Brasil. Secretaria de Atenção à Saúde, Departamento de Atenção Especializada. Manual de Educação em Saúde: auto-cuidado na doença falciforme. Brasília: Editora do Ministério da Saúde; 2008. p. 78

5. Powars DR, Elliott-Mills DD, Chan L, Niland J, Hiti AL, Opas LM. Chronic renal failure in sickle cell disease: risk factors, clinical course, and mortality. Ann Intern Med. 1991;115(8):614-20. https://doi.org/10.7326/0003-4819-115-8-614

6. Powars DR, Chan LS, Hiti A, Ramicone E, Johnson C. Outcome of sickle cell anemia: a 4-decade observational study of 1056 patients. Medicine (Baltimore). 2005;84(6):363-76. https:// doi.org/10.1097/01.md.0000189089.45003.52

7. Kassim AA, Sharma D. Hematopoietic stem cell transplantation for sickle cell disease: The changing landscape. Hematol Oncol Stem Cell Ther. 2017;10(4):259-66. https://doi.org/10.1016/j. hemonc.2017.05.008

8. Platt OS, Brambilla DJ, Rosse WF, Milner PF, Castro O, Steinberg $\mathrm{MH}$, et al. Mortality in sickle cell disease. Life expectancy and risk factors for early death. N Engl J Med. 1994;330(23):163944. https://doi.org/10.1056/NEJM199406093302303

9. Moher D, Liberati A, Tetzlaff J, Altman DG; PRISMA Group. Preferred reporting items for systematic reviews and metaanalyses: the PRISMA statement. PLoS Med. 2009;6(7):e1000097. https://doi.org/10.1371/journal.pmed.1000097 
10. CASP Checklist [Internet]. Oxford: Critical appraisal skills programme; 2018 [cited on Jun. 19, 2019]. Available from: https://casp-uk.net/casp-tools-checklists/

11. Aygun B, Mortier NA, Smeltzer MP, Hankins JS, Ware RE. Glomerular hyperfiltration and albuminuria in children with sickle cell anemia. Pediatr Nephrol. 2011;26(8):1285-90. https://doi.org/10.1007/s00467-011-1857-2

12. Gosmanova EO, Zaidi S, Wan JY, Adams-Graves PE. Prevalence and progression of chronic kidney disease in adult patients with sickle cell disease. J Investig Med. 2014;62(5):804-7. https://doi.org/10.1097/01.JIM.0000446836.75352.72

13. Lebensburger J, Johnson SM, Askenazi DJ, Rozario NL, Howard TH, Hilliard LM. Protective role of hemoglobin and fetal hemoglobin in early kidney disease for children with sickle cell anemia. Am J Hematol. 2011;86(5):430-2. https:// doi.org/10.1002/ajh.21994

14. Saraf SL, Zhang X, Kanias T, Lash JP, Molokie RE, Oza B, et al. Haemoglobinuria is associated with chronic kidney disease and its progression in patients with sickle cell anaemia. $\mathrm{Br}$ J Haematol. 2014;164(5):729-39. https://doi.org/10.1111/ bjh. 12690

15. Yee MM, Jabbar SF, Osunkwo I, Clement L, Lane PA, Eckman JR, et al. Chronic kidney disease and albuminuria in children with sickle cell disease. Clin J Am Soc Nephrol. 2011;6(11):262833. https://doi.org/10.2215/CJN.01600211

16. Silva Junior $G B$, Libório $A B$, Vieira APF, Couto Bem $A X$, Lopes Filho AS, Figueiredo Filho $A C$, et al. Evaluation of renal function in sickle cell disease patients in Brazil. Braz J Med Biol Res. 2012;45(7):652-5. https://doi.org/10.1590/s0100$879 \times 2012007500079$

17. Naik RP, Derebail VK. The spectrum of sickle hemoglobinrelated nephropathy: from sickle cell disease to sickle trait. Expert Rev Hematol. 2017;10(12):1087-94. https://doi.org/ 10.1080/17474086.2017.1395279

18. Powars DR, Chan LS, Hiti A, Ramicone E, Johnson C. Outcome of sickle cell anemia: A 4-decade observational study of 1056 patients. Medicine (Baltimore). 2005;84(6):363-76. https:// doi.org/10.1097/01.md.0000189089.45003.52

19. Laurin LP, Nachman PH, Desai PC, Ataga KI, Derebail VK. Hydroxyurea is associated with lower prevalence of albuminuria in adults with sickle cell disease. Nephrol Dial Transplant. 2014;29(6):1211-8. https://doi.org/10.1093/ndt/gft295

20. Lu CC, Wang GH, Lu J, Chen PP, Zhang Y, Hu ZB, et al. Role of podocyte injury in glomerulosclerosis. Adv Exp Med Biol. 2019;1165:195-232. https://doi.org/10.1007/978-981-13$8871-2 \_10$

21. Greka A, Mundel P. Cell biology and pathology of podocytes. Annu Rev Physiol. 2012;74:299-323. https://doi.org/10.1146/ annurev-physiol-020911-153238
22. Gordeuk VR, Sachdev V, Taylor JG, Gladwin MT, Kato G, Castro OL. Relative systemic hypertension in patients with sickle cell disease is associated with risk of pulmonary hypertension and renal insufficiency. Am J Hematol. 2008;83(1):15-8. https:// doi.org/10.1002/ajh.21016

23. Goldberg MA, Brugnara C, Dover GJ, Schapira L, Charache S, Bunn F. Treatment of Sickle Cell Anemia with Hydroxyurea and Erythropoietin. N Engl J Med. 1990;323(6):366-72. https:// doi.org/10.1056/NEJM199008093230602

24. Taylor JG 6th, Nolan VG, Mendelsohn L, Kato GJ, Gladwin MT, Steinberg MH. Chronic hyper-hemolysis in sickle cell anemia: association of vascular complications and mortality with less frequent vasoocclusive pain. PLoS One. 2008;3(5):e2095. https://doi.org/10.1371/journal.pone.0002095

25. Haydek JP, Taborda C, Shah R, Reshamwala PA, McLemore $M L$, Rassi FE, et al. Extreme hyperbilirubinemia: An indicator of morbidity and mortality in sickle cell disease. World J Hepatol. 2019;11(3):287-93. https://doi.org/10.4254/wjh.v11.i3.287

26. Madu AJ, Ubesie A, Ocheni S, Chinawa J, Madu KA, Ibegbulam OG, et al. Important clinical and laboratory correlates of glomerular filtration rate in sickle cell anemia. Niger J Clin Pract. 2015;18(5):633-7. https://doi.org/10.4103/11193077.154220

27. Simonsen $\mathrm{O}$, Grubb A, Thysell H. The blood serum concentration of cystatin C (gamma-trace) as a measure of the glomerular filtration rate. Scand J Clin Lab Invest. 1985;45(2):97-101. https://doi.org/10.3109/00365518509160980

28. Unal S, Kotan C, Delibas A, Oztas Y. Cystatin C, Beta2 Microglobulin, $\mathrm{N}$-Acetyl-beta-D-glucosaminidase, Retinol-Binding Protein, and Endothelin 1 Levels in the Evaluation of Sickle Cell Disease Nephropathy. Pediatr Hematol Oncol. 2015;32(4):250-7. https:// doi.org/10.3109/08880018.2013.810317

29. Voskaridou E, Terpos E, Michail S, Hantzi E, Anagnostopoulos A, Margeli $A$, et al. Early markers of renal dysfunction in patients with sickle cell/beta-thalassemia. Kidney Int. 2006;69(11):203742. https://doi.org/10.1038/sj.ki.5000248

30. Kaze FF, Kengne AP, Atanga LC, Monny Lobe M, Menanga $\mathrm{AP}$, Halle MP, et al. Kidney function, urinalysis abnormalities and correlates in equatorial Africans with sickle cell disease. Clin Kidney J. 2013;6(1):15-20. https://doi.org/10.1093/ckj/ sfs100

31. Scheinman JI. Sickle cell disease and the kidney. Nat Clin Pract Nephrol. 2009;5(2):78-88. https://doi.org/10.1038/ ncpneph1008

32. Wesson DE. The initiation and progression of sickle cell nephropathy. Kidney Int. 2002;61(6):2277-86. https://doi. org/10.1046/j.1523-1755.2002.00363.x

33. Shetty $A$, Matrana MR. Renal medullary carcinoma: a case report and brief review of the literature. Ochsner J. 2014;14(2):270-5 